\title{
Implementasi Sistem Pengukuran Redaman Serat Optik Pada Lekukan
}

\section{Measurement System Implementation Optical Fiber Reducing On Slows}

\author{
Lince Markis, Vera Veronica \& Uzma Septima \\ Jurusan Teknik Elektro Politeknik Negeri Padang Kampus Limau Manis Padang \\ Telp.0751-72590 Fax.0751-72576 Email:lincemarkis@yahoo.com, \\ veraveronica@yahoo.co.id,u_septima@yahoo.com
}

\begin{abstract}
Dutch electronics company, Philips, is testing LiFi technology. LiFi or Light Fidelity is able to deliver broadband internet connections through light intermediaries. According to Philips Lightning Olivia Qiu's Chief Innovation Officer, LiFi technology has great potential for today's digital era. Indeed, if you look at the current world trend, internet connection has now become one of the daily needs of humans just like the lighting needs produced by Philips massively. When radio frequency becomes increasingly dense, the light spectrum is a large untapped resource [kompas, 2018]. Based on the facts stated that communication using optical fiber becomes very important so that to optimize the fiber optic system an implementation of optical fiber attenuation measurements is made. In this study, the method of implementing the measurement of optical fiber attenuation at a wavelength of $875 \mathrm{~nm}$ was introduced. This optical fiber attenuation measurement utilizes transmitter and receiver optical fiber systems that are connected to optical fibers with different lengths and curves. Attenuation for the length of 1, 3, 4, 5 and 6 meter optical fibers is 0.034, 0.558, 0.625, 1.156 and $2.170 \mathrm{~dB}$ respectively in straight optical fiber conditions. The power values for each optical fiber with lengths 1, 3,4,5 and $6 \mathrm{~m}$ respectively are 52.21, 51.58, 50.81, 45.08 and $30.05 \mathrm{~dB}$ when there are curves. The attenuation values of each $1,3,4,5$ and $6 \mathrm{~m}$ optical fiber lengths are - 0.746, - 0.8, - 0.864, - 1,384 and - 3,145 dB respectively when there is a curve.
\end{abstract}

Keywords : Optical Fiber, Optical Fiber Attenuation, Wavelength.

\section{PENDAHULUAN}

PT. Sarana Global Indonesia saat ini tengah berupaya membantu pemerintah dalam pembangunan infrastruktur. Salah satunya adalah membangun jaringan telekomuikasi yang lebih cepat dengan menggunakan Cable Barge atau kabel bawah laut. Presiden Direktur Sarana Global Indonesia Chandra Arie Setiawan mengklaim, jaringan telekomunikasi menggunakan cable barge ini lebih cepat jika dibandingkan satelit. Kalau satelit itu kecepatannya megabyte sedangkan untuk cable barge ini terabyte [suara.com 2017]. Selain itu jika komunikasi hanya mengandalkan satelit, maka kapasitasnya akan terbatas, jika server satelit down atau mengalami masalah maka jaringan telekomunikasi akan terganggu. "Lalu dari segi perawatan satelit perawatannya tiap 15 tahun sedangkan cable barge ini minimal 25 tahun. Teknologi kabel laut ini menggunakan serat optik. Pada sistem transmisi serat optik, cahaya yang merambat sepanjang serat optik akan mengalami peredaman, sehingga disisi penerima kekuatan cahaya akan menjadi lemah. Disisi lain kekuatan cahaya dari dioda laser terbatas dan photodetector memiliki sensitifitas tertentu untuk dapat mendeteksi sinyal optik. Oleh karena itu untuk dapat mengoperasikan sistem telekomunikasi, rugi- rugi optik harus dibuat pada level yang lebih tinggi dari level sensitivitas yang dimiliki oleh photodetector. Level rugi-rugi optik yang diperbolehkan sudah ditentukan untuk masing- masing sistem telekomunikasi.

Lengkungan dapat terjadi akibat hal-hal yang tidak sengaja, sehingga mengakibatkan arah 
propagasi cahaya di dalam serat optik berbelok dari arah transmisi semula keluar dari core ke arah cladding. Jenis lengkungan dapat dikelompokkan ke dalam dua macam, yaitu microbending dan macrobending. Microbending. Microbending lebih sulit untuk dideteksi karena jari-jari kelengkungan mendekati jari-jari inti serat optik, sehingga mengakibatkan adanya kopling daya antar mode. Rugi microbending dikurangi dengan menggunakan jaket pelindung serat yang fleksibel. Macrobending dapat diartikan sebagai rugi-rugi yang terjadi jika jari-jari kelengkungan jauh lebih besar dari jari-jari inti serat optik. Hal ini disebabkan oleh efek makroskopik seperti adanya belokan kecil pada serat itu sendiri.

Pada penelitian ini diperkenalkan metode implementasi pengukuran redaman serat optik pada panjang gelombang $875 \mathrm{~nm}$. Pengukuran redaman serat optik ini memanfaatkan pemancar dan penerima sistem serat optik yang terhubung ke serat optik dengan panjang dan lengkungan yang berbeda-beda. Prinsip kerja metode pengukuran redaman serat optik ini adalah dengan mengukur tegangan dan arus pada sisi pemancar dan penerima. Parameter tegangan ini yang dijadikan referensi sebagai nilai redaman dari sistem serat optik.

\section{METODOLOGI}

Implementasi sistem pengukuran redaman serat optik pada panjang gelombang $875 \mathrm{~nm}$. Beberapa bagian dalam konfigurasi sistem ini memiliki tujuan khusus meliputi :

- Perencanaan sistem alat pengukuran redaman serat optik berupa pengukuran tegangan pada sisi penerima yang dijadikan sebagai acuan nilai redaman sistem komunikasi serat optik.

- Perencanaan sistem pengukuran untuk beberapa panjang dan lengkungan yang berbeda-beda.

- Memberikan alternatif pengukuran redaman pada sistem serat optik untuk tipe serat optik yang berbeda.

Perancangan sistem pengukuran redaman pada serat optik dilakukan dengan membentuk sistem pengukuran tegangan pada serat optik. Sistem ini dibentuk dari sebuah pemancar optik dan saluran transmisi berupa serat optik serta sebuah penerima optik. Sebuah pemancar optik yang bekerja pada panjang gelombang $875 \mathrm{~nm}$ di hubungkan ke serat optik dengan panjang dan kelengkungan tertentu. Serat optik pada sisi ujung lainya di hubungkan dengan sebuah penerima serat optik.

Pada sistem transmisi serat optik, cahaya yang merambat sepanjang serat optik akan mengalami peredaman, sehingga diujung jauh (sisi penerima) kekuatan cahaya akan menjadi lemah. Disisi lain kekuatan cahaya dari dioda laser terbatas dan photodetector memiliki sensitifitas tertentu untuk dapat mendeteksi sinyal optik. Oleh karena itu untuk dapat mengoperasikan sistem telekomunikasi, rugi- rugi optik (total loss) harus dibuat pada level yang lebih tinggi dari level sensitivitas yang dimiliki oleh photodetector. Level rugi-rugi optik yang diperbolehkan sudah ditentukan untuk masing- masing sistem telekomunikasi.

Lengkungan dapat terjadi akibat hal-hal yang tidak sengaja, sehingga mengakibatkan arah propagasi cahaya di dalam serat optik berbelok dari arah transmisi semula keluar dari core ke arah cladding. Jenis lengkungan dapat dikelompokkan ke dalam dua macam, yaitu microbending dan macrobending. Microbending. Microbending lebih sulit untuk dideteksi karena jari-jari kelengkungan mendekati jari-jari inti serat optik, sehingga mengakibatkan adanya kopling daya antar mode. Rugi microbending dikurangi dengan menggunakan jaket pelindung serat yang fleksibel. Macrobending dapat diartikan sebagai rugi-rugi yang terjadi jika jari-jari kelengkungan jauh lebih besar dari jari-jari inti serat optik. Hal ini disebabkan oleh efek makroskopik seperti adanya belokan kecil pada serat itu sendiri.

\section{A. Perancangan Sistem Pengukuran redaman pada serat optik}

Perancangan sistem pengukuran redaman pada serat optik dilakukan dengan membentuk sistem pengukuran tegangan 
pada serat optik. Sistem ini dibentuk dari sebuah pemancar optik dan saluran transmisi berupa serat optik serta sebuah penerima optik. Sebuah pemancar optik yang bekerja pada panjang gelombang $875 \mathrm{~nm}$ di hubungkan ke serat optik dengan panjang dan kelengkungan tertentu. Serat optik pada sisi ujung lainya di hubungkan dengan sebuah penerima serat optik.

\section{B.Perancangan pengukuran redaman serat optik}

Data pengukuran redaman yang dihasilkan melalui tahap menentukan karakteristik dari sumber optik yang digunakan, dimana sumber optik yang dipakai berupa dioda laser yang bekrja pada panjang gelombang 875 nm. Data dari karakteristik dioda pemancar yang digunakan berupa tegangan tertentu dengan melihat indikasi arus maksimum. Data karakteristik dioda pemancar ini digunakan untuk mengetahui tegangan kerja dari dioda tersebut. Tegangan kerja dioda pemancar diberikan pada sisi pemancar sehingga dioda yang difungsikan sebagai sumber optik dipastikan dapat bekerja. Secara keseluruhan bagian dalam konfigurasi sistem ini meliputi :

- Perencanaan sistem serat optik secara keseluruhan.

- Perencanaan hardware terdiri dari serat optik dengan panjang yang bervariasi dan kelengkungan yang berbeda.

- Penggunaan software labsoft berupa alat ukur virtual yang digunakan untuk mendapatkan hasil berupa arus dan tegangan sebagai implementasi nilai redaman.

\section{Blok Diagaram Rancangan Sistem}

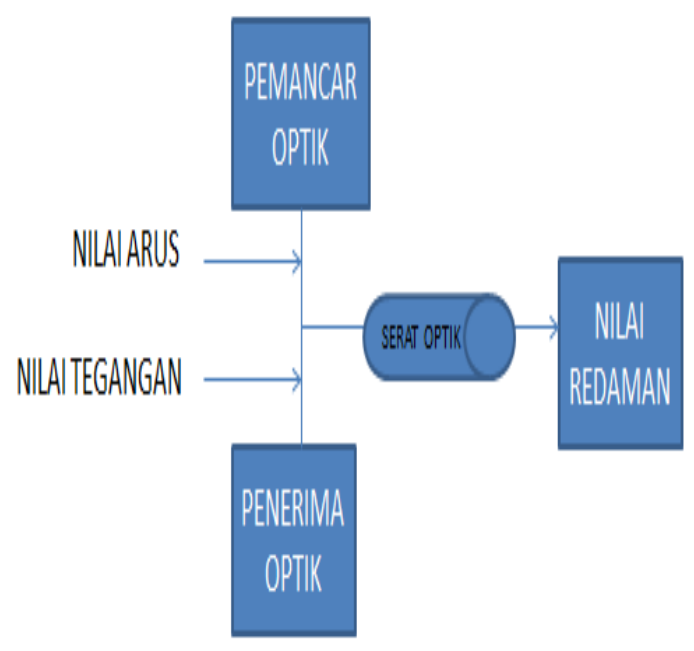

Gambar 1. Blok Diagram Rancangan Sistem

Blok diagram sistem dalam melakukan pengukuran dengan memanfaatkan hasil redaman dari serat optik. Nilai redaman dilakukan dengan kondisi serat optik lurus dan ada lekukan.

\section{Rumusan Pengolahan data}

Metode pengukuran yang digunakan adalah mengukur tegangan dengan memberikan input arus yang bervariasi pada serat optik. Pengukuran dilakukan dengan menggunakan perangkat pemancar dan penerima optik. Pemancar dan penerima optik dihubungkan dengan serat optik yang memiliki panjang dan lengkungan yang berbeda-beda. Hasil pengukuran berupa tegangan yang dapat di implementasikan terhadap nilai redaman yang terjadi sepanjang serat optik yang digunakan.

\section{HASIL DAN PEMBAHASAN}

Percobaan yang telah dilakukan menghasilkan beberapa hal yang dapat dijabarkan sebagai berikut :

\section{A. Pengukuran daya serat optik.}

Pengukuran daya dilakukan untuk panjang serat optik yang bervariasi yaitu 1, 3, 4, 5 dan 6 meter. Pengukuran dilakukan menggunakan power meter sebagai referensi 
daya standar. Pengukuran dilakukan dengan urutan sebagai berikut :

1. Power meter di seting sesuai dengan panjang gelombang yang digunakan oleh serat optik yaitu $875 \mathrm{~nm}$.

2. Ujung serat optik salah satunya dipasang pada sumber optik power meter dan ujung lainnya pada power meter. Serat optik yang digunakan memiliki panjang 1, 3, 4, 5, dan 6 meter. Pengukuran dilakukan secara bergantian untuk setiap panjang serat optik.

Tabel. 1

Hasil Pengukuran Data Serat Optik dengan Power Meter

\begin{tabular}{|c|c|c|}
\hline & $\begin{array}{c}\text { Panjang ( } \\
\text { meter ) }\end{array}$ & Daya ( dB ) \\
\hline 1 & 1 & 62.98 \\
\hline 2 & 3 & 55.48 \\
\hline 3 & 4 & 54.37 \\
\hline 4 & 5 & 48.27 \\
\hline 5 & 6 & 38.19 \\
\hline
\end{tabular}

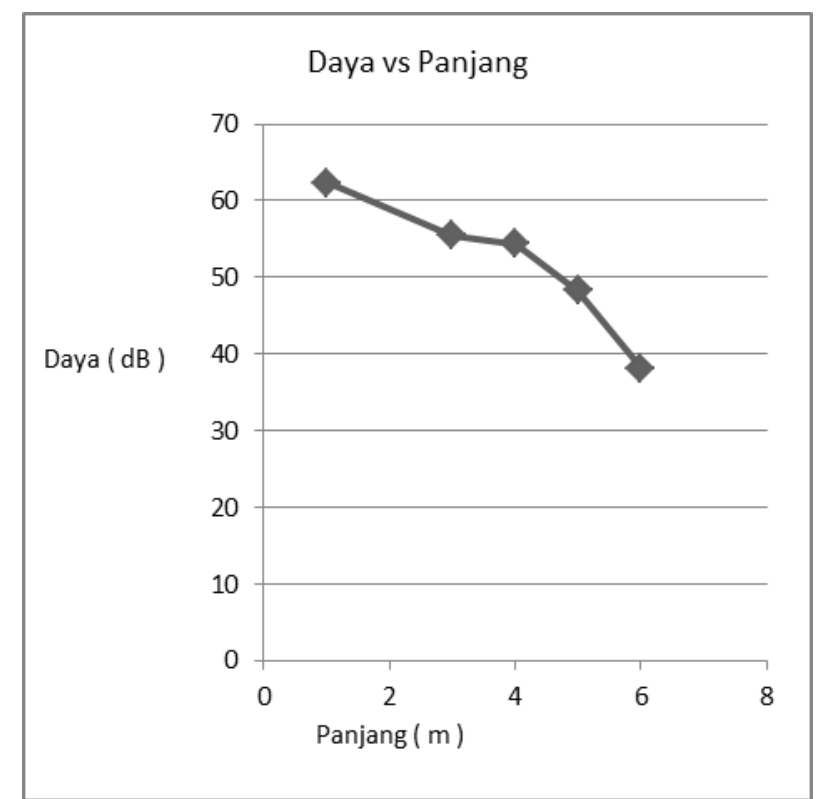

Gambar 2. Grafik Daya terhadap Panjang

Serat Optik menggunakan Power Meter

Tabel 1 menunjukan nilai hasil pengukuran daya serat optik menggunakan power meter. Serat optik dengan panjang yang bervariasi sampai 5 meter menunjukan nilai daya semakin berkurang dengan semakin panjangnya serat optik.
B. Pengukuran daya serat optik menggunakan Sumber Optik

- Pengukuran daya dilakukan untuk panjang serat optik yang bervariasi yaitu $1,3,4,5$, dan 6 . dan kondisi serat optik dalam posisi tidak ada lekukan ( lurus ).

- Pengukuran dilakukan menggunakan rangkaian sumber optik. Pengukuran dilakukan dengan urutan sebagai berikut :

1. Sumber optik di seting sesuai dengan panjang gelombang yang digunakan oleh serat optik yaitu 875 nm.

2. Power meter di seting sesuai dengan panjang gelombang yang di gunakan serat optik.

3. Ujung serat optik salah satunya dipasang pada sumber optik dan ujung lainnya pada power meter. Serat optik yang digunakan memiliki panjang 1, 3, 4, 5 dan 6 . Pengukuran dilakukan secara bergantian untuk setiap panjang serat optik.

Tabel. 2

Hasil Pengukuran Data Serat Optik dengan Sumber Optik

\begin{tabular}{|l|c|c|}
\hline No. & $\begin{array}{c}\text { Panjang } \\
\text { meter })\end{array}$ & Daya ( dB ) \\
\hline 1 & 1 & 62 \\
\hline 2 & 3 & 54.97 \\
\hline 3 & 4 & 54.12 \\
\hline 4 & 5 & 47.89 \\
\hline 5 & 6 & 37.92 \\
\hline
\end{tabular}




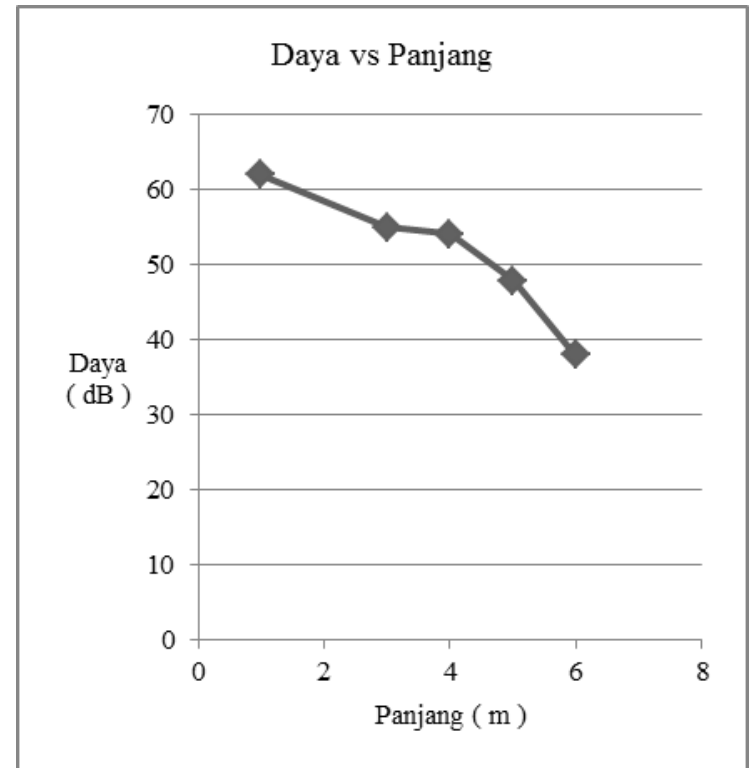

Gambar 3. Grafik Daya terhadap Panjang Serat Optik menggunakan Sumber Optik

Tabel 2 hasil pengukuran daya pada setiap panjang serat optik dengan menggunakan sumber optik. Nilai daya yang dihasilkan berbanding terbalik dengan panjang serat optik.

Pengukuran daya $(\mathrm{dB})$ terhadap parameter panjang $(\mathrm{m})$ serat optik menggunakan sumber optik menghasilkan perubahan nilai panjang serat optik bervariasi terhadap nilai daya dimana perubahan nilai parameter berbanding terbalik.

\section{Perhitungan Redaman Serat Optik}

Tabel. 3

Hasil Pengukuran Redaman Serat Optik

\begin{tabular}{|l|c|c|c|}
\hline No. & $\begin{array}{c}\text { Panjang } \\
(\text { meter })\end{array}$ & $\begin{array}{c}\mathrm{a}(\mathrm{dB}) \\
\mathrm{PM}\end{array}$ & $\begin{array}{c}\mathrm{a}(\mathrm{dB}) \\
\mathrm{S}\end{array}$ \\
\hline 1 & 1 & 0.033 & -0.034 \\
\hline 2 & 3 & 0.517 & -0.558 \\
\hline 3 & 4 & -0.605 & -0.625 \\
\hline 4 & 5 & -1.122 & -1.156 \\
\hline 5 & 6 & -2.139 & -2.170 \\
\hline
\end{tabular}

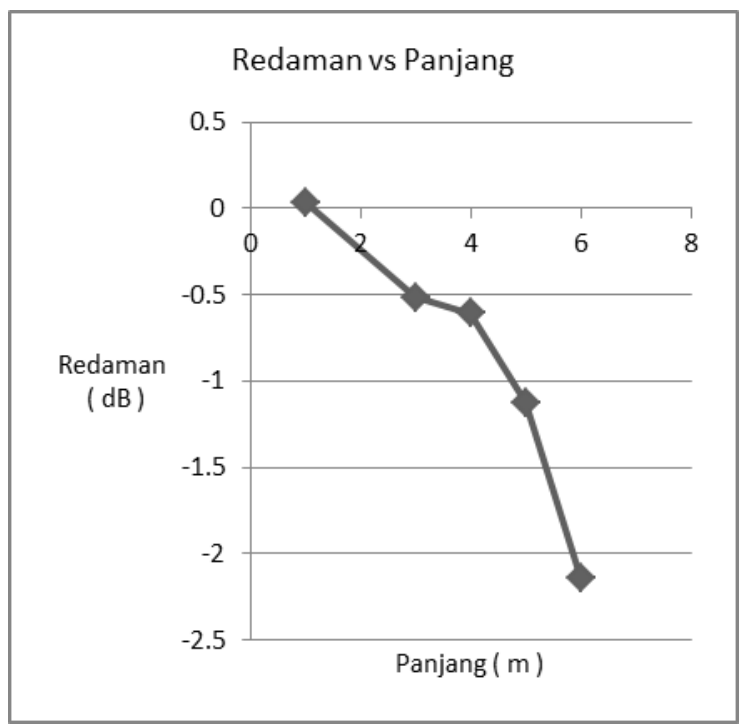

Gambar 4. Grafik Redaman terhadap Panjang Serat Optik menggunakan Power Meter

Nilai parameter redaman ( $\mathrm{dB}$ ) terhadap panjang ( $\mathrm{m}$ ) serat optik menggunakan power meter adalah berbanding lurus.

Tabel 3 menunjukan hasil redaman pada saat serat optik memiliki panjang yang berbeda-beda. Variasi panjang serat optik menunjukan nilai yang berbanding lurus terhadap nilai redaman itu sendiri.

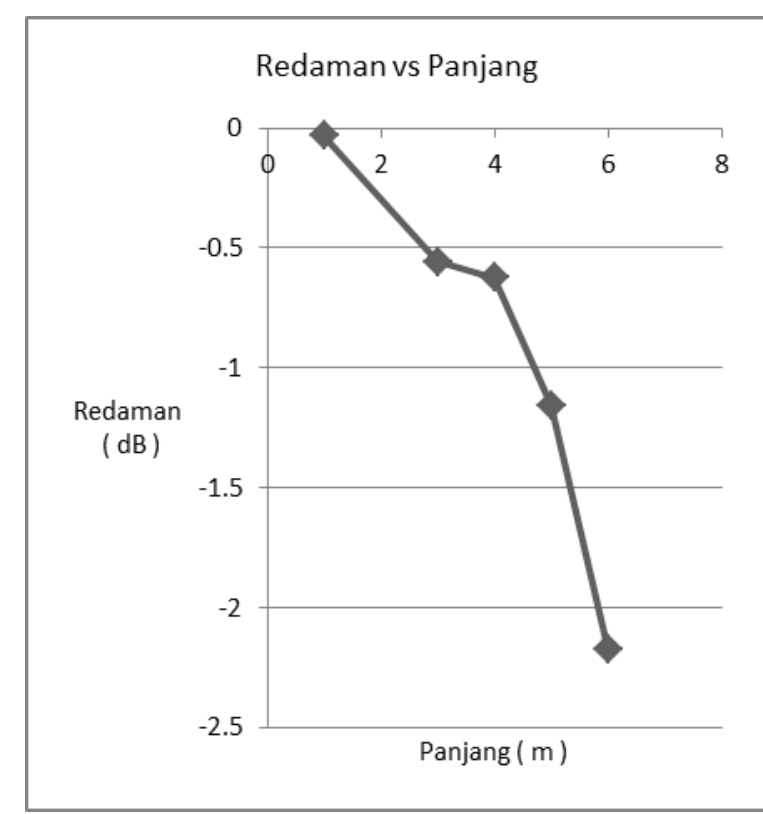

Gambar 5. Grafik Redaman terhadap Panjang Serat Optik menggunakan Sumber Optik

Nilai parameter redaman ( $\mathrm{dB}$ ) terhadap panjang ( $\mathrm{m}$ ) serat optik menggunakan sumber optik adalah berbanding lurus. 


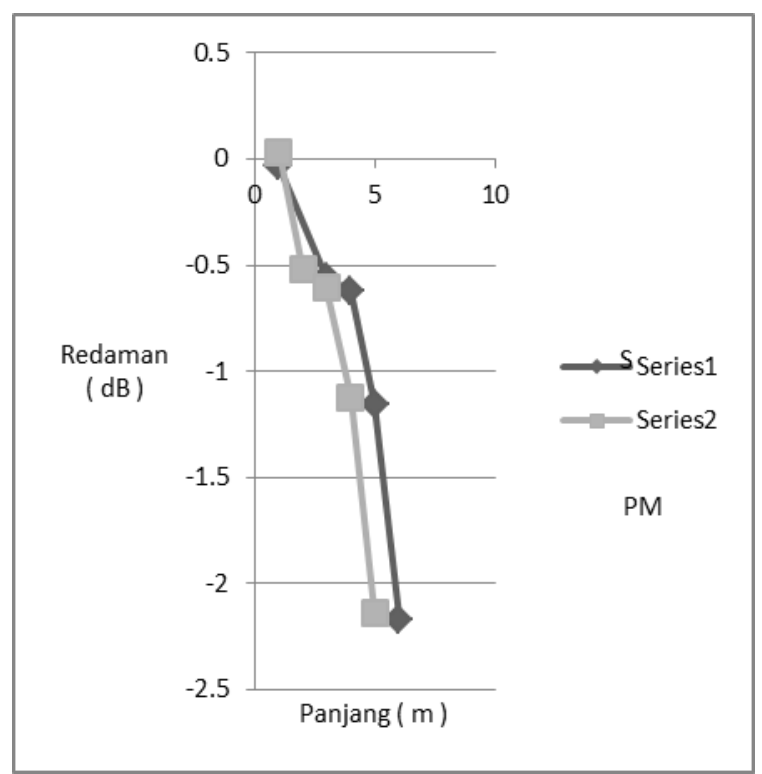

Gambar 6. Grafik Redaman terhadap Panjang Serat Optik

Perbandingan pengukuran menggunakan sumber optik dan power meter menunjukan hasil yang sama dimana parameter panjang terhadap redaman adalah berbanding lurus.

\section{Pengukuran daya serat optik kondisi ada lekukan}

Tabel. 4

Hasil Pengukuran Daya Serat Optik

Lekukan

\begin{tabular}{|l|c|c|}
\hline No. & $\begin{array}{c}\text { Panjang } \\
(\text { meter })\end{array}$ & Daya ( dB ) \\
\hline 1 & 1 & 52.21 \\
\hline 2 & 3 & 51.58 \\
\hline 3 & 4 & 50.81 \\
\hline 4 & 5 & 45.08 \\
\hline 5 & 6 & 30.05 \\
\hline
\end{tabular}

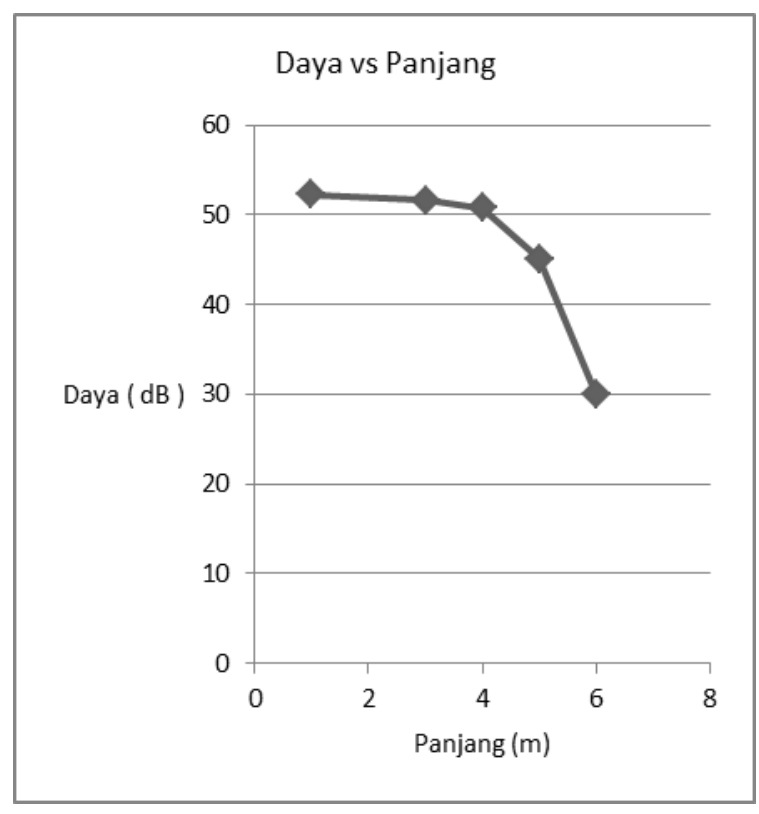

Gambar 7. Grafik Daya terhadap Panjang Serat

Optik saat ada lekukan

Lekukan yang terjadi sepanjang serat optik mempengaruhi nilai daya yang dihasilkan sepanjang serat optik. Nilai daya berbanding terbalik dengan nilai panjang serat optik. Nilai daya yang dihasilkan pada serat optik yang mengalami lekukan lebih besar dibandingkan dengan nilai daya yang dihasilkan pada saat serat optik dalam kondisi lurus.

Pada tabel 4 merupakan pengukuran daya sepanjang serat optik dengan kondisi serat optik dalam keadaan terjadi lekukan. Nilai daya yang dihasilkan berbanding terbalik terhadap nilai redaman.

\section{E. Perhitungan Redaman Serat Optik saat ada lekukan}

Tabel. 5

Hasil Pengukuran Daya Serat Optik Lengkungan

\begin{tabular}{|c|c|c|}
\hline No. & $\begin{array}{c}\text { Panjang } \\
(\text { meter } \\
)\end{array}$ & $\mathrm{a}(\mathrm{dB})$ \\
\hline & & -0.746 \\
\hline 1 & 1 & -0.8 \\
\hline 2 & 3 & -0.864 \\
\hline 3 & 4 & -1.384 \\
\hline 4 & 5 & -3.145 \\
\hline 5 & 6 & \\
\hline
\end{tabular}




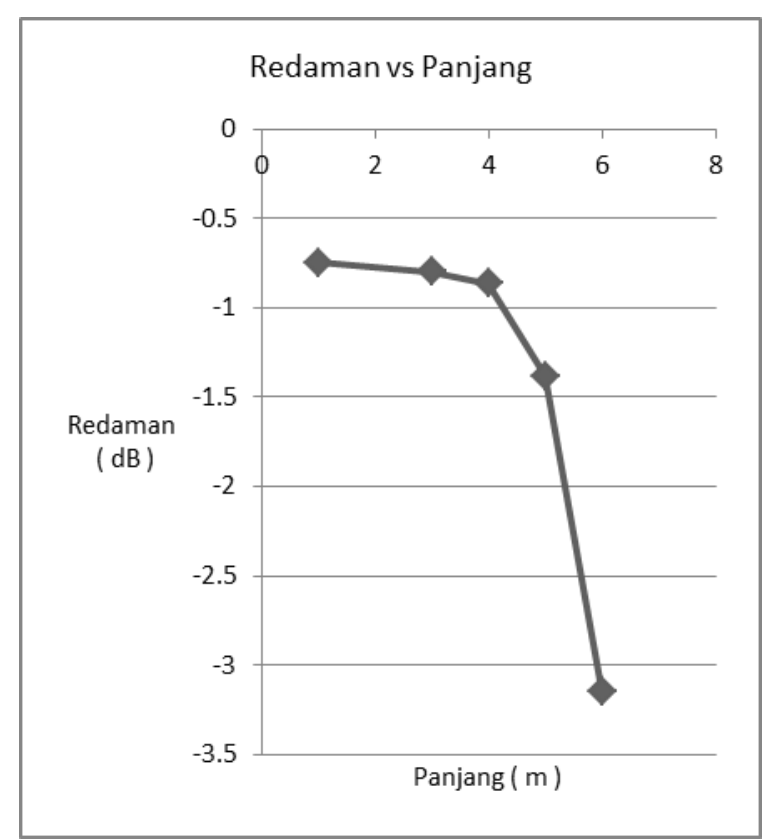

Gambar 9. Grafik Redaman terhadap Panjang Serat Optik saat ada lekukan

Lekukan yang terjadi sepanjang serat optik mempengaruhi nilai redaman yang dihasilkan sepanjang serat optik. Nilai redaman berbanding terbalik dengan nilai panjang serat optik. Nilai redaman yang dihasilkan pada serat optik yang mengalami lekukan lebih besar dibandingkan dengan nilai daya yang dihasilkan pada saat serat optik dalam kondisi lurus.

Tabel 5 adalah hasil pengukuran dari nilai redaman terhadap panjang serta optik dengan kondisi ada lekukan. Nilai redaman disepanjang serat optik yang ada lekukan adalah berbanding lurus terhadap panjang serat optik.

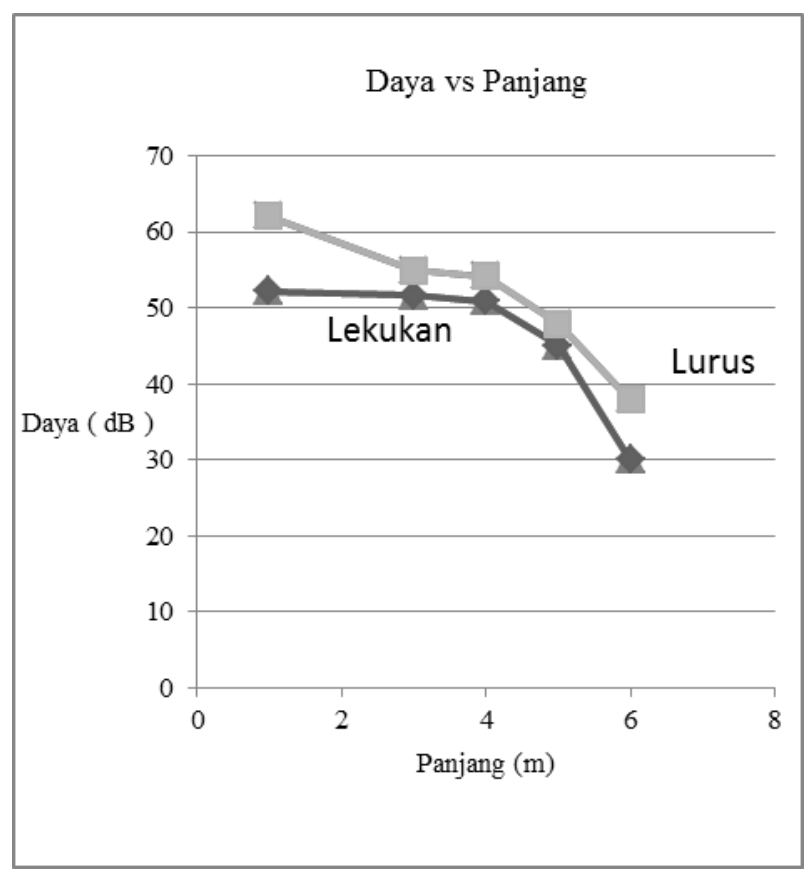

Gambar 8. Grafik Daya terhadap Panjang Serat Optik saat ada lekukan dan Lurus

Perbandingan nilai parameter daya terhadap panjang serat optik disaat ada lekukan dan tanpa lekukan adalah saat ada lekukan nilai daya semakin kecil dengan semakin panjangnya serat optik.

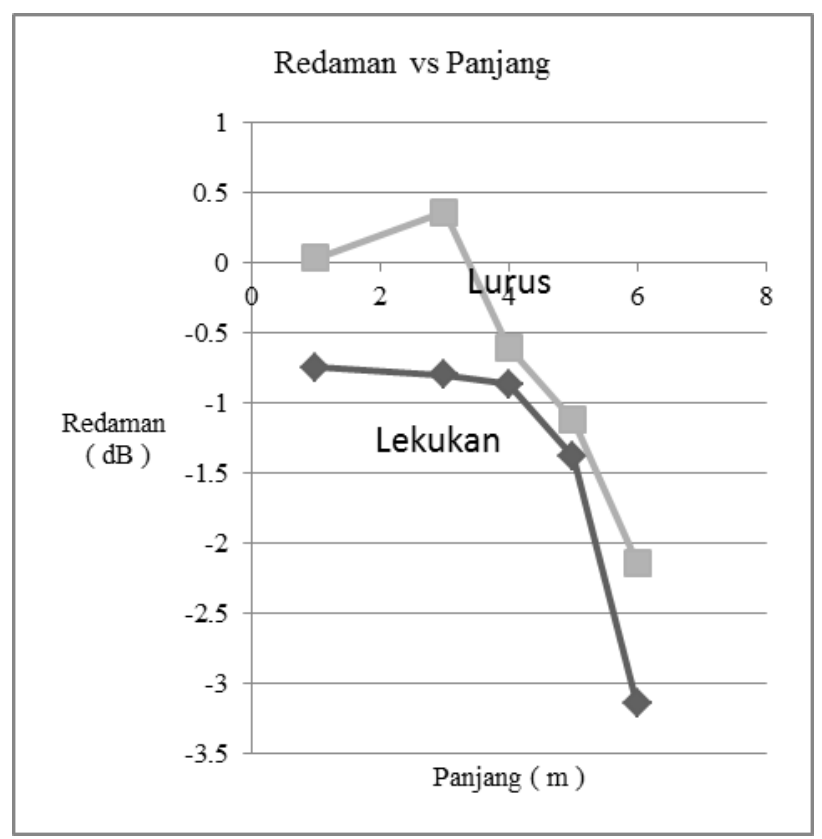

Gambar 10. Grafik Redaman terhadap Panjang Serat Optik saat ada lekukan dan lurus

Perbandingan nilai parameter redaman terhadap panjang serat optik disaat ada lekukan dan tanpa lekukan adalah saat ada 
lekukan nilai redaman semakin besar dengan semakin panjangnya serat optik.

Tabel. 6

Hasil Pengukuran Daya Serat Optik

\begin{tabular}{|c|c|c|c|}
\hline No. & $\begin{array}{c}\text { Panjang } \\
(\text { meter })\end{array}$ & $\begin{array}{c}\mathrm{P}(\mathrm{dB}) \\
\text { Lurus }\end{array}$ & $\begin{array}{c}\mathrm{P}(\mathrm{dB}) \\
\text { Lekukan }\end{array}$ \\
\hline 1 & 1 & 62.98 & 52.21 \\
\hline 2 & 3 & 55.48 & 51.58 \\
\hline 3 & 4 & 54.37 & 50.81 \\
\hline 4 & 5 & 48.27 & 45.08 \\
\hline 5 & 6 & 38.19 & 30.05 \\
\hline
\end{tabular}

Tabel. 7

Hasil Pengukuran Redaman Serat Optik

\begin{tabular}{|c|c|c|c|}
\hline No. & $\begin{array}{r}\text { Panjang } \\
(\text { meter })\end{array}$ & $\begin{array}{r}\mathrm{a}(\mathrm{dB}) \\
\text { Lurus }\end{array}$ & $\begin{array}{c}\mathrm{a}(\mathrm{dB}) \\
\text { Lekukan }\end{array}$ \\
\hline 1 & 1 & -0.034 & -0.746 \\
\hline 2 & 3 & -0.558 & -0.8 \\
\hline 3 & 4 & -0.625 & -0.864 \\
\hline 4 & 5 & -1.156 & -1.384 \\
\hline 5 & 6 & -2.170 & -3.145 \\
\hline
\end{tabular}

Perbandingan nilai daya pada tabel 6 menunjukan bahwa nilai daya yang dihasilkan saat serat optik berada pada kondisi ada lekukan dengan kondisi serat optik lurus menunjukan nilai daya disepanjang serat optik yang terdapat lekukan menhasilkan nilai daya yang semakin kecil dibandingkan nilai daya pada saat serat optik lurus.

Tabel 7 merupakan perbandingan nilai redaman yang dihasilkan akibat adanya lekukan disepanjang serat optik terhadap serat optik dalam kondisi lurus. Redaman yang dihasilkan memiliki nilai redaman lebih besar pada saat serat optik mengalami lekukan dibanding serat optik dalam kondisi lurus.

\section{SIMPULAN}

1. Nilai daya pada masing-masing serat optik dengan panjang $1,3,4,5$ dan $6 \mathrm{~m}$ berturuttururt adalah 62, 54.97, 54.12, 47.89 dan $37.92 \mathrm{Db}$ saat lurus.

2. Nilai redaman masing-masing panjang serat optik 1, 3, 4, 5 dan $6 \mathrm{~m}$ berturut- turut adalah $0.034,0.558,0.625,1.156$ dan $2.170 \mathrm{~dB}$ saat lurus.

3. Kenaikan nilai redaman terhadap panjang serat optik adalah berbanding lurus.

4. Nilai daya pada masing-masing serat optik dengan panjang $1,3,4,5$ dan $6 \mathrm{~m}$ berturuttururt adalah 52.21, 51.58, 50.81, 45.08 dan $30.05 \mathrm{~dB}$ saat ada lekukan.

5. Nilai redaman masing-masing panjang serat optik 1,3,4, 5 dan 6 m berturut-turut adalah - 0.746, - 0.8, - 0.864, - 1.384 dan $3.145 \mathrm{~dB}$ saat ada lekukan.

\section{DAFTAR PUSTAKA}

[1] O Mandasari “Analisis daya hilang pada serat optik melengkung menggunakan metode geometris dan FDTD" Penelitian dan Pengembangan Telekomunikasi, Kendali, Komputer, Elektrik, dan Elektronika (TEKTRIKA) "Vol 1 No 1, Januari 2016

[2] S Riyadi "Kontribusi kerugian akibat sambungan pada saluran transmisi serat optik" Simetris, Vol. 7 No.1, April 2016.

[3] W. Agil " Analisis rugi-rugi konektor, rugi-rugi penyambungan pada serat optik” USU, vol 11 No 29, April 2015. 